\title{
UPAYA MENINGKATKAN HASIL BELAJAR MATEMATIKA MENGGUNAKAN METODE REALISTIC MATHEMATICEDUCATION (RME) BERBANTUAN MEDIA CONGKAKAN DAN DRINKING STRAW KELAS IV MI AL-MUSTAJABAH TAHUN PELAJARAN 2017/2018
}

OLEH : Yulia Mawaddah* Dedy Setyawan**

\begin{abstract}
ABSTRAK
Hasil belajar Matematika Peserta Didik kelas IV MI Al-Mustajabah masih rendah. Guru perlu memilih metode dan media yang tepat dalam mencapai tujuan pembelajaran. Artikel ini membahas hasil penelitian tindakan kelas yang mendeskripsikan pelaksana pembelajaran matematika dengan menggunakan metode Realistic Mathematic Education (RME) berbantuan media congkakan dan drinking straw untuk meningkatkan hasil belajar Peserta Didik pada meteri KPK dan FPB. Hasil penelitian dari 2 siklus menunjukkan adanya peningkatan dari skor tes akhir siklusI ( $58 \%$ ) keskor tes akhir siklus II ( $91 \%$ )
\end{abstract}

Kata Kunci :Realistic Mathematic Education (RME) berbantuan media congkakan dan drinking straw. KPK dan FPB. Hasil belajar

\section{PENDAHULUAN}

Marti (Sundayana, Rostina 2014) berpendapat bahwa, objek Matematika yang bersifat abstrak tersebut merupakan kesuitan tersendiri yang harus dihadapi peserta didik dalam mrmpelajari Matematika. Tidak hanya peserta didik, Guru pun juga mengalami kendala dalam mengerjakan Matemtika terkait sifatnya yang abstrak tersebut. Konsep-konsep Matematika dipahami dengan mudah bila bersifat konkrit. Karenannya pengajaran Matematika harus dilakukan secara bertahap. Pembelajaran Matematika harus dimulai dari tahapan konkrit. Lalu diarahkan pada tahapan semi konkrit, dan pada akhirnya peserta didik dapat berpikir dan memahami Matematika secara abstrak. Ahmad Susanto (2012:194) agar kemampuan berkomunikasi matematika peserta didik dapat berkembang, kemampuan pemahaman matematika peserta didik juga perlu ditingkatkan, perlu pengembangan pemahaman matematika.Jadi dapat disimpulkan dari menurut berbagai ahli bahwa tujuan pembelajaran matematika adalah untuk kemampuan pemahaman tentang segala unsur dan ilmu matematika.

Berdasarkan wawancara pada Hasil belajar Matematika peserta didik masih rendah. Permasalahan tersebut juga diperkuat dengan data kuantitatif yang diperoleh dari hasil evaluasi pembelajaran Matematika, yaitu sebagian besar siswa kelas IV MI Al-Mustajabah masih belum mencapai KKM, hal ini ditunjukan dengan data, dari 24 siswa hanya 13 siswa $(54 \%)$ yang mendapatkan nilai di atas Kriteria Ketuntasan Minimal (KKM) yaitu 70, sedangkan sisanya 
11 siswa (65\%) nilainya di bawah KKM (70). Dengan rincian nilai tertinggi 90 dan nilai terendah 50.Data tersebut didapat dari wali kelas IV MI Al-Mustajabah pada hari senin tanggal 24 juli 2017. Peneliti merasa tertarik untuk melakukan perbaikan pembelajaran dengan menggunakan model pembelajaran yang belum pernah digunakan di kelas tersebut. Kompetensi dasar penjumlahan dan pengurangan berbagai bentuk pecahan, pada materi ini lah terdapat beberapa permasalahan yang telah dijelaskan sebelumnya. Penelitian ini diharapkan dapat meningkatkan hasil belajar Matematika peserta didik apabila menerapkan Model Pembelajaran Realistic Mathematics Education (RME) dengan menggunakan media Congkakan dan Drinking Straw dalam kegiatan pembelajaran.

Berdasarkan permasalahan diatas guru dapat memfasilitasi siswa dengan mengembangkan bahan ajar metode Realistic Mathematics Education (RME) yaitu dengan mengaitkan masalah matematika dengan lingkungan sehari-hari dan pengalaman nyata yang sering dialami sehingga siswa diajak berfikir bagaimana menyelesaikan masalah-masalah yang diberikan dengan menggunakan pendekatan yang tidak abstrak lagi dengan barbantuan Media Congkakan dan Drinking Straw untuk menarik perhatian peserta didik.
Treffers (Shoimin Aris 2013) ada dua jenis matematiasasi, yaitu matematisasi horizontal dan vartikel. (1). Matematika horizontal peserta didik menggunakan matematika untuk mengorganisasikan dan menyelesaikan masalah yang ada pada situasi nyata. Contoh matematisasi horizontal adalah pengidentifikasi, perumusan dan pemvisualan masalah dalam cara yang berbeda, merumuskan masalah kehidupan sehari-hari kedalam bentuk matematika.(2). Matematisasi vartikel berkaitan dengan proses pengorganisasian kembali pengetahuan yang telah diperoleh dalam simbol matematika yang lebih abstrak. Contoh matematisasi vartikel adalah menghaluskan/memperbaiki model, menggunakan model yang berbeda, memadukan dan mengombinasikan model, membuktikan keteraturan, merumuskan konsep metematika yang baru, dan menggeneralisasian.

Berdasarkan pada uraian diatas, pada dasarnya prinsip atau ide yang mendasari Realistic Mathematic Education (RME) adalah situasi ketika peserta didik diberi kesempatan untuk menemukan kembali ide-ide matematika. Berdasrkan situasi realistic, peserta didik didorong untuk mengonstruksi sendiri masalah realistic, karena masalah yang dikonstruksi oleh peserta didik akan menarik peserta didik lain untuk memecahkannya. Proses yang berhubungan dalam berpikir dan pemecahan masalah ini 
dapat meningktkan hasil mereka dalam masalah. (Shoimin Aris 2013)

Adapun yang menjadi tujuan dalam penelitian ini adalah untuk dapat mengetahui apakah penggunaan Model Realistic Mathematic Education (RME)berbantuan media pembelajaran Congkakan dan Drinking Straw dapat meningkatkan minat dan hasil belajar peserta didik dalam mata pelajaran Matematika pada materi FPB dan KPK di MI AlMustajabah. Adapun manfaat dari penelitian ini adalah Meningkatkan daya serap dan memotifasi peserta didik dalam pemebelajaran, Agar menjadikan inovasi terhadap Kepala Sekolah dan bisa memberikan masukan kepada guru untuk harus inofatif dan variatif dalam memilih dan menggunakan strategi, model dan metode pembelajaran agar hasil belajar peserta didik tidak rendah.Untuk pesarta didik agar pembelajaran lebih menyenangkan dan tujuan pembelajaran bisa tercapai dan hasil belajar Peserta Didik meningkat.

\section{Metode Penelitian}

Jenis penelitian ini adalah penelitian tindakan kelas (PTK) yang terdiri atas empat tahap yaitu, perencanaan, pelaksanaan observasi da refleksi. Menurut Arikunto (2013 :3) yang dimaksud dengan PTK adalah pencermatan terhadap kegiatan belajar berupa suatu tindakan yang sengaja dimunculkan dan terjadi dalam suatu kelas secara bersama.

Penelitian ini dilakukan di Madrasah Ibtidaiyah Al-Mustajabah yang terletak di Jl. Pemuda km 15,5 Kuala Kapuas. Dengan subjek 24 orang peserta didik terdiri dari 14 orang perempuan, dan 10 laki-laki. Kelas IV semester ganjil tahun ajaran 2017/2018 yaitu pada bulan september 2017.

Data yang dikumpulkan dari penelitian ini adalah data dari : (1) hasil pengamatan observasi observasi terhadap aktivitas Guru dan aktivitas Peserta Didik selama proses pembelajaran. (2) hasil tes untuk mengetahui peningkatan hasil belajara Peserta Didik yang dilaksanakan pada akhir siklus. Perangkat pembelajaran yang digunakan adalah silabus, RPP, dan LKPD

Data hasil observasi yang dilakukan akan dianalisis dengan memberikan skor untuk penentuan kategori.

$\begin{gathered}\text { Presentase Skor Rata-rata } \\ \text { jumlahskor }\end{gathered}$ jumian sḱor maḱsismai
kriteria keberhasilan tindakan
ditentukan sebagai berikut :
$4 \quad=$ Sangat Baik
$3-3,9=$ Baik
$2-2,9=$ Cukup
$1-1,9=$ Kurang
Presentasi ketuntasan belajar
secara klasikal dihitung dengan cara
membandingkan jumlah peserta
didik yang mencapai KKM dengan
jumlah populai kemudian dikalikan
100\%.


Presentasi ktuntasan belajar

klasikal

$\frac{\sum j u m l a h \text { skor }}{\sum j u m i a n \text { skor maḱsismai }} \times 100 \%$

Presentasi belajar dikatakan meningkat apabila scara klasikal minimal $85 \%$ peserta didik mencapai KKM yang ditetapkan disekolah yaitu 75

\section{Hasil}

Hasil penelitian yang diperoleh dalam penelitian ini berupa data hasil pre tes.

\section{Tabel 1}

Hasil observasi pre tes

\begin{tabular}{|c|c|c|c|}
\hline Jumlah populasi & Tuntas Belajar & Tidak tuntas & Nilai KKM \\
\hline 24 & 6 & 18 & 70 \\
\hline \multicolumn{2}{|c|}{$\begin{array}{l}\text { Pada pree tes ini dimana proses } \\
\text { pembelajarannya tidak menggunakan }\end{array}$} & \multicolumn{2}{|c|}{$\begin{array}{l}\text { dilihatketuntasaan hasil belajar } \\
\text { peserta didik pada tes awal (pre test) }\end{array}$} \\
\hline metode Realisti & Mathematic & \multicolumn{2}{|c|}{ adalah $25 \%$. Yaitu dari 24 orang } \\
\hline $\begin{array}{l}\text { Education (RME). } \\
\text { perhitungan ketunt } \\
\text { secara klasikal, }\end{array}$ & $\begin{array}{l}\text { rdasarkan hasil } \\
\text { an hasil belajar } \\
\text { maka dapat }\end{array}$ & \multicolumn{2}{|c|}{$\begin{array}{l}\text { Peserta Didik, } 6 \text { orang yang } \\
\text { mendapat nilai } \geq 70 \text { dengan nilai rata- } \\
\text { rata } 54\end{array}$} \\
\hline
\end{tabular}

Tabel 2

Hasil ketuntasan belajar peserta didik pada siklus I dan siklus II.

\begin{tabular}{|l|l|l|l|l|l|l|}
\hline & $\begin{array}{l}\text { Jumlah } \\
\text { populasi }\end{array}$ & Tuntas belajar & $\begin{array}{l}\text { Tidak } \\
\text { tuntas }\end{array}$ & $\begin{array}{l}\text { Nilai } \\
\text { KKM }\end{array}$ & $\begin{array}{l}\text { Nilai Rata } \\
\text { rata }\end{array}$ & $\begin{array}{l}\text { Presentasi } \\
\text { ketuntasan }\end{array}$ \\
\hline Siklus I & 24 & 14 & 10 & 70 & 68 & $58 \%$ \\
\hline Siklus II & 24 & 22 & 2 & 70 & 85 & $91 \%$ \\
\hline
\end{tabular}

Dapat dilihat dari tabel 2 pada siklus melanjutkan siklus II dan I Guru menggunakan metode Realistic Mathematic Education mendapatkan hasil 22 orang Peserta Didik yang sudah tuntas dan (RME) erbantuan media Congkakan, persentasi ketuntasan mencapai $91 \%$. tetapi peserta didik yang tuntas hanya 14 orang presentasi ketuntasan hanya $58 \%$. Hal tersebut dikarenakan media yang kurang diminati oleh Peserta Ddidik. Maka dari itu Guru Hal tersebut dikarenaka Guru mengganti media Congkakan menjadi Drinking Straw. Media tersebut cukup disenangi sehingga tujua pembelajaran dapat tercapai.

\section{Tabel 3}

\section{Hasil pengamatan aktivitas Guru}




\begin{tabular}{|l|l|l|l|l|}
\hline & P-I & P-II & $\begin{array}{l}\text { Nilai Rata } \\
\text { rata }\end{array}$ & Kategori \\
\hline Siklus I & 3,25 & 3,62 & 55 & Baik \\
\hline Siklus II & 3,81 & 3,68 & 3,75 & Baik \\
\hline
\end{tabular}

Tabel 4Hasil pengamatan Peserta Didik

\begin{tabular}{|l|l|l|l|l|}
\hline & P-I & P-II & $\begin{array}{l}\text { Nilai Rata } \\
\text { rata }\end{array}$ & Kategori \\
\hline Siklus I & 3 & 3,6 & 3,3 & Baik \\
\hline Siklus II & 3,4 & 3,6 & 3,5 & Baik \\
\hline
\end{tabular}

\section{Pembahasan}

Pada pembelajaran KPK dan FPB dalam penelitian ini dilaksanakan pembelajaran terbagi dalam empat tahap. Yaitu memahami masalah kontekstual, menyelesaikan masalah kontekstual, membandingkan dan mendiskusikan jawaban, menyimpulkan

Pertama yaitu memahami masalah kontekstual. Pada kegiatan ini siswa memahami masalah kontekstual yang didiskusikan dalam kelompok masing-masing. Materi disajikan dalam bentuk masalah mampu memotivasi siswa untuk memecahkannya.

Masalah yang diberikan
adalah masalah yang berkaitan
dengan kehidupan sehari-hari dan
disajikan dalam bentuk soal cerita
atau masalah yang dapat
dibayangkan oleh siswa. Akan tetapi
siswa membutuhkan waktu yang
lama dalam memahami maksud
permasalahan. Hal ini dikarenakan
siswa belum terbiasa dalam

menghadapi dan memecahkan masalah realistik.

Dalam memahami masalah kontekstual, siswa diminta untuk bertanya kepada teman kelompoknya akan tetapi siswa diberi kesempatan untuk bertanya kepada peneliti jika siswa mengalami kesulitan. Peneliti tidak langsung memberikan jawaban terhadap pertanyaan siswa tetapi membimbing siswa dengan pertanyaan yang dapat memancing siswa untuk menemukan jawaban yang benar melalui pengetahuan yang telah mereka miliki.

Pada tahap menyelesaikan masalah ini yang berisikan kegiatan belajar mengajar dengan menggunakan metode Realistik Mathematik Education (RME) dan media Congkakan.Membuat lembar aktivitas kegiatan peserta didik dan lembar aktivitas kegiatan guru yang akan diisi oleh pengamat atau observasi.Pada siklus II proses pembelajaran tetap menekankan pada hasil belajar Matematika. Tujuan pembelajaran pun masih tetap sama dengan siklus Idan dengan 
menggunakan Metode Realistik Mathematic Education (RME) namun peneliti menggunakan media yang berbeda dari siklus I yaitu menggunakna media Drinking Straws dan cara pembelajaran yang berbeda.

Dalam mendiskusikan dan membandingkan jawaban terjadi diskusi kelas. Peneliti meminta beberapa kelompok untuk mempresentasikan hasil kerja kelompoknya. Pada tahap ini terjadi interaksi siswa dengan siswa dan siswa dengan guru. Guru sebagai fasilitator hanya mengarahkan, mengendalikan jalannya diskusi hingga siswa tetap terarah sesuai dengan yang diharapkan. Sebagian besar siswa pada kegiatan ini mampu berperan aktif meskipun ada beberapa siswa yang masih tidak percaya diri untuk mengemukakan pendapatnya.

Tahap akhir yaitu menyimpulkan. Pada tahap ini, siswa diminta membuat kesimpulan tentang apa yang telah dikerjakan pada masalah sebelumnya. Guru mengarahkan dan membimbing siswa dalam membuat kesimpulan. Selanjutnya guru mengadakan evaluasi melalui tanya jawab lisan untuk mengecek kembali pemahaman siswa. Evaluasi ini dilakukan guru pada beberapa siswa yang dipilih secara acak.

\section{Kesimpulan}

Berdasarkan hasil penelitian dapat disimpulkan sebagai berikut :
Aktivitas

belajar

Matematikadengan Menggunakan Metode PembelajaranRealistik Mathematik Education Berbantuan media Congkakan dan Drinking Straws pada materi ajar KPK dan FPB di MI Al-Mustajabah kelas IVTahun Pelajaran 2017/2018 menjadi baik . Hal ini dapat dilihat dari Aktivitas peserta didik pada Siklus I dengan kategori baik dengan skor rata-rata 3,3 dan pada siklus II ada peningkatan skor rata-rata 3,5 dengan kategori baik.

Ada peningkatan hasil belajar dengan Menggunakan Metode PembelajaranRealistik Mathematik Education Berbantuan media Congkakan dan Drinking Straws pada materi ajar KPK dan FPB di MI Al-Mustajabah kelas IVTahun Pelajaran 2017/2018. Hal ini dapat diketahui Rata - rata pada pre tes mendapathasil 54 dengan persentase ketuntasan klasikal $25 \%$. Pada siklus I diperoleh hasil rata - rata 68 dengan persentase ketuntasan klasikal $58 \%$ dan pada siklus II diperoleh hasil rata - rata 85 dengan persentase ketuntasan klasikal $91 \%$.

\section{DAFTAR PUSTAKA}

Arikunto Suharsimi . (2006). Penelitian Tindakan Kelas (PTK),

Jakarta: PT Bumi Aksara.

Shoimin, A. (2016), 68 Model Pembelajaran Inovatif dalam Kurikulum 2013. Yogyakarta Ar-ruzz Media

Sundayana, Rustina (2014) Media Dan Alat Peraga dalam Pembelajaran Matematika. Bandung Alfabeta 
Pedagogik Jurnal Pendidikan, Oktober 2017, Volume 12 No 2 (7-13)

Susanto, Ahmad, (2012) Teori Sekolah Dasar, Jakarta Belajar \& Pembelajaran di Prenadamedia Group. 